\title{
ROLE OF THE N-TERMINAL PEPTIDE OF AMELOGENIN ON OSTEOBLASTIC DIFFERENTIATION OF HUMAN MESENCHYMAL STEM CELLS
}

\author{
R. Olivares-Navarrete ${ }^{1, *}$, K. Vesper ${ }^{2}$, S. L. Hyzy ${ }^{1}$, A. Almaguer-Flores ${ }^{3}$, B. D. Boyan ${ }^{1,2}$ and Z. Schwartz ${ }^{1,4}$
}

${ }^{1}$ Department of Biomedical Engineering, Virginia Commonwealth University, Richmond, VA, USA

${ }^{2}$ Wallace H. Coulter Department of Biomedical Engineering, Georgia Institute of Technology, Atlanta, GA, USA

${ }^{3}$ Facultad de Odontologia, Universidad Nacional Autonoma de Mexico, Mexico City, Mexico

${ }^{4}$ Department of Periodontics, University of Texas Health Science Center at San Antonio, San Antonio, TX, USA

\begin{abstract}
Porcine enamel matrix derivative (pEMD), a complex mixture of proteins and peptides including full-length amelogenin protein, splice variants, and proteolytic peptides, is used clinically with a carrier to regenerate supportive tissue around teeth. During application, pEMD self-assembles as nanospheres and precipitates as a three-dimensional matrix to facilitate cell migration and differentiation. Amelogenin, the primary constituent of pEMD, stimulates osteoblast differentiation, but it is unclear what specific roles other components of pEMD play in determining biological response. This study examined the potential of one constituent of pEMD, the N-terminal amelogenin peptide (NTAP), to promote osteoblastic differentiation of human mesenchymal stem cells (MSCs) and to elucidate possible signaling pathways involved. Effects of porcine NTAP on MSC cultures were compared to those of recombinant human amelogenin. While amelogenin induced MSC osteoblastic differentiation, a more robust osteoblastic response was seen after NTAP treatment. A phospho-kinase proteasome array measuring phosphorylation of 35 proteins indicated that protein kinase C (PKC), extracellular signal-regulated kinase $1 / 2$ (ERK1/2), and $\beta$-catenin were highly phosphorylated by NTAP. This was confirmed by measuring PKC activity and levels of phospho-ERK $1 / 2$ and $\beta$-catenin. Both amelogenin and NTAP increased PKC, but NTAP induced higher phosho-ERK $1 / 2$ and phospho- $\beta$-catenin than amelogenin. ERK1/2 inhibition blocked both amelogeninand NTAP-induced increases in RUNX2, ALP, OCN, COL1, and BMP2. The results demonstrate that NTAP induces osteogenic differentiation of MSCs via PKC and ERK1/2 activation and $\beta$-catenin degradation. NTAP may be an active bone regeneration component of amelogenin, and may play this role in pEMD-stimulated periodontal regeneration.
\end{abstract}

Keywords: Mesenchymal stem cells, differentiation, enamel matrix derivative, amelogenin, local factors.

*Address for correspondence:

Rene Olivares-Navarrete, D.D.S., Ph.D.

Department of Biomedical Engineering

School of Engineering, Virginia Commonwealth University 601 West Main Street, Suite 396, Richmond, VA 23284, USA

Telephone Number: 1-804-828-8718

FAX Number: 1-804-828-9866

E-mail: ronavarrete@vcu.edu

\section{Introduction}

Enamel matrix proteins are secreted by cells of the Hertwig epithelial root sheath in the enamel organ during tooth development. Porcine enamel matrix derivative (pEMD) is a purified acid extract obtained from 6-month-old pig tooth germs (Grandin et al., 2012). It contains full-length amelogenin and its splice variants and proteolytic cleavage peptides, as well as other proteins, and it is marketed commercially in a formulation containing a carrier for treatment of periodontal defects. Clinically, pEMD is hypothesized to achieve its effects by mimicking the biological processes of natural tooth development (Gestrelius et al., 2000). It acts as a scaffolding structure, allowing selective colonization of cells. During application, pEMD undergoes self-assembly and precipitates on the denuded and conditioned root surface as nanospheres. This precipitation process occurs immediately at physiological $\mathrm{pH}$ and body temperature, forming an extracellular matrix that covers the root surface and releases factors (Lyngstadaas et al., 2001).

The commercial formulation of pEMD has also been tested outside the oral environment, including repair of long bone defects (Kawana et al., 2001) and treatment of acute and chronic skin wounds (Mirastschijski et al., 2004). However, despite the apparent success of pEMD clinically, little is known about the roles of its individual components. Whereas commercial pEMD formulations are consistent in their composition to meet regulatory standards, laboratory-generated enamel matrix derivatives may vary in the relative content of specific proteins or peptides for a variety of reasons, including species of origin, age of the tissue, and differences in extraction methodology. Thus, it has been difficult to identify which constituents contribute to specific biological outcomes.

In general, enamel matrix derivatives are composed of $90 \%$ amelogenin (Brookes et al., 1995). The remaining $10 \%$ includes proline-rich enamelin, tuftelin, and tuft serum proteins, but also amelogenin isoforms resulting from alternative splicing (Bartlett and Simmer, 1999; Brookes et al., 1995). Smaller amelogenin peptides formed by proteolytic cleavage of the $20 \mathrm{kDa}$ amelogenin protein (Nagano et al., 2009), including leucine-rich amelogenin peptide (LRAP) and tyrosine-rich amelogenin peptide (TRAP), have been identified, and it has been suggested that these are the functional amelogenin signaling peptides (Fincham and Moradian-Oldak, 1993). In previous studies, analysis of pEMD by high performance liquid chromatography revealed the presence of three main components: a $20 \mathrm{kDa}$ peptide, two peptides of 12 and 
$9 \mathrm{kDa}$, and a small $5 \mathrm{kDa}$ peptide (Mumulidu et al., 2007). We chose to focus on the smallest component, the $5 \mathrm{kDa}$ peptide (NTAP) in this study, which contains the TRAP sequence and corresponds to the $\mathrm{N}$-terminus of amelogenin. Other studies have reported the effects of LRAP and amelogenin, including the effects of the C-terminal amelogenin peptide (Le Norcy et al., 2011).

Enamel matrix derivatives have been studied extensively both in vitro and in vivo. Amelogenin has been shown to stimulate osteoblast differentiation (Olivares-Navarrete et al., 2013) and to increase the mitogen activated protein kinase (MAPK) extracellular signal-regulated kinase (ERK1/2) (Yao et al., 2011), implicating this signaling cascade in its mechanism of action. However, the specific roles of other components of these extracts on cell response are not well understood. We previously showed that porcine NTAP can stimulate osteoblast differentiation in committed osteoblasts, but it is not known whether this peptide can induce osteoblast differentiation in multipotent human mesenchymal stem cells (MSCs).

Osteogenic differentiation of MSCs is a well-orchestrated process, beginning with activation of transcription factors (runt-related transcription factor 2 [RUNX2] and osterix [OSX]). These result in transcription of genes important in differentiation and matrix mineralization and prevent MSC differentiation towards other mesenchymal lineages (Komori, 2010). In addition to inducing osteoblast differentiation in multipotent MSCs, bone regeneration involves new blood vessel formation and net new bone formation over bone resorption. Differentiated osteoblasts produce factors that enhance osteogenesis in a paracrine manner, including promoting angiogenesis via vascular endothelial growth factor (VEGF), promoting matrix synthesis via transforming growth factor beta 1 (TGF $\beta-1)$ and bone morphogenetic protein 2 (BMP2), and inhibiting osteoclastic bone resorption via osteoprotegerin (OPG) (Mundy, 1991; Raines et al., 2010; Schwartz et al., 2009).

In the current study, we investigated the effects of NTAP on gene expression and protein synthesis by MSCs in comparison to effects of recombinant human amelogenin (rAmel) as a control. Our goal was to determine if porcine NTAP can induce osteoblastic differentiation of human MSCs and if so, whether the signaling pathways involved are similar to those used by amelogenin.

\section{Materials and Methods}

\section{Cell culture}

Human bone marrow derived MSCs were obtained from Lonza Biosciences (Walkersville, MD, USA) and cultured in Mesenchymal Stem Cell Growth Medium (MSCGM, Lonza). Cells were cultured at $37{ }^{\circ} \mathrm{C}$ with $5 \% \mathrm{CO}_{2}$ and $100 \%$ humidity.

\section{Proteins}

Institut Straumann (Basel, Switzerland) provided recombinant human amelogenin (rAmel) and porcine NTAP. NTAP was extracted and purified from porcine EMD as previously described (Mumulidu et al., 2007).
Lyophilized protein or peptide was reconstituted in $0.1 \%$ acetic acid and sterile filtered through a low binding protein filter (Millipore, Billerica, MA, USA) to produce a $1 \mathrm{mg} /$ $\mathrm{mL}$ stock solution. Further dilutions of proteins were performed into culture media.

\section{Osteoblastic differentiation of MSCs}

At confluence, MSCs were treated with vehicle $(0.01 \%$ acetic acid), $1 \mu \mathrm{g} / \mathrm{mL}$ or $10 \mu \mathrm{g} / \mathrm{mL}$ of protein or peptide (rAmel or NTAP) for $24 \mathrm{~h}$. After $24 \mathrm{~h}$, conditioned media were collected and assayed. A commercially available radioimmunoassay (Biomedical Technologies, Inc., Stoughton, MA, USA) was used to measure osteocalcin. Levels of osteoprotegerin (OPG), total (active plus latent) transforming growth factor beta-1 (TGF- $\beta 1$ ), and vascular endothelial growth factor (VEGF) were measured using commercially available ELISAs (DuoSets, R\&D Systems, Minneapolis, MN, USA) following the manufacturer's instructions.

At harvest, the cell monolayers were rinsed twice with phosphate buffered saline and lysed in $0.05 \%$ Triton X-100 (Sigma-Aldrich, St. Louis, MO, USA). Total DNA was quantified using PicoGreen ${ }^{\circledR}$ (Quant-iT ${ }^{\text {TM }}$ PicoGreen dsDNA kit, Invitrogen, Carlsbad, CA, USA) following the manufacturer's instructions. Briefly, lysates were incubated with $1 \mu \mathrm{L}$ PicoGreen ${ }^{\circledR}$ for $5 \mathrm{~min}$, and fluorescence intensity measured (Beckman Coulter DTX880 Fluorescent Plate Reader, Brea, CA, USA) using excitation at $480 \mathrm{~nm}$ and emission at $520 \mathrm{~nm}$. Concentration was calculated using a Lambda DNA standard. Alkaline phosphatase enzyme activity was assayed in the cell lysate by quantifying the release of $p$-nitrophenol from $p$-nitrophenylphosphate at $\mathrm{pH}$ 10.2. Results were normalized to total protein content of cell lysates (Thermo Scientific Pierce BCA Protein Assay, Thermo Fisher, Rockford, IL, USA).

\section{Gene expression}

At confluence, MSCs were treated with either vehicle $(0.01 \%$ acetic acid $)$ or concentrations of protein/peptide (rAmel or NTAP) for $12 \mathrm{~h}$. After $12 \mathrm{~h}$, RNA was isolated using TRIzol ${ }^{\circledR}$ (Invitrogen). RNA was quantified using a NanoDrop 1000 spectrophotometer (Thermo Scientific, Waltham, MA, USA). $1 \mu \mathrm{g}$ of RNA was used in reverse transcription PCR to create cDNA using random primers (Promega, Madison, WI, USA) and Omniscript reverse transcriptase (Qiagen, Valencia, CA, USA). Resulting cDNA was used to quantify using real-time quantitative PCR with gene-specific primers using an iQ5 System (BioRad, Hercules, CA). Fluorescence values were quantified as starting quantities using a standard curve generated from known nucleic acid concentrations of untreated MSCs. Genes are presented as normalized to glyceraldehyde 3-phosphate dehydrogenase (GAPDH). Primer sequences (Table 1) were designed using Beacon Designer (Premier Biosoft International, Palo Alto, CA, USA) and synthesized by Eurofins MWG Operon (Huntsville, AL, USA).

\section{Biochemical assays}

The effect of rAmel or NTAP on protein phosphorylation was investigated using a Human Kinase Proteome Profiler Array (R\&D Systems), which examined phosphorylation 
Table 1. Primer sequences used for real-time qPCR.

\begin{tabular}{|c|c|c|c|}
\hline Gene & & Primer Sequence & Accession Number \\
\hline \multirow{2}{*}{ ALP } & $\mathrm{F}$ & TGT GGA GTA TGA GAG TGA CG & \multirow{2}{*}{ NM_000478.3 } \\
\hline & $\mathrm{R}$ & GAA GTG GGA GTG CTT GTA TC & \\
\hline \multirow{2}{*}{ BMP2 } & $\mathrm{F}$ & GCG TGA AAA GAG AGA CTG C & \multirow{2}{*}{ NM_00120 } \\
\hline & $\mathrm{R}$ & CCA TTG AAA GAG CGT CCA C & \\
\hline \multirow{2}{*}{ COL1 } & $\mathrm{F}$ & GAC CTC TCT CCT CTG AAA CC & \multirow{2}{*}{ NM_000088.3 } \\
\hline & $\mathrm{R}$ & AAC TGC TTT GTG CTT TGG G & \\
\hline \multirow{2}{*}{ OCN } & $\mathrm{F}$ & GTG ACG AGT TGG CTG ACC & \multirow{2}{*}{ NM_19917. } \\
\hline & $\mathrm{R}$ & TGG AGA GGA GCA GAA CTG G & \\
\hline \multirow{2}{*}{ OPG } & $\mathrm{F}$ & ACC ACT ACT ACA CAG ACA GC & \multirow{2}{*}{ NM_00254 } \\
\hline & $\mathrm{R}$ & CAA GCA GAA CTC TAT CTC AAG G & \\
\hline \multirow{2}{*}{ RUNX2 } & $\mathrm{F}$ & GTC TCA CTG CCT CTC ACT TG & \multirow{2}{*}{ NM_001024630 } \\
\hline & $\mathrm{R}$ & СAC ACA ТCТ ССТ ССС ТTC TG & \\
\hline \multirow{2}{*}{ GAPDH } & $\mathrm{F}$ & GCT CTC CAG AAC ATC ATC C & \multirow{2}{*}{ NM_002046.5 } \\
\hline & $\mathrm{R}$ & TGC TTC ACC ACC TTC TTG & \\
\hline
\end{tabular}

of 46 proteins. Confluent cultures of MSCs were treated with $1 \mu \mathrm{g} / \mathrm{mL}$ rAmel or NTAP for $30 \mathrm{~min}$. After incubation, cells were lysed and analyzed by modified Western blot. Membranes were imaged by chemiluminescence (VersaDoc, Bio-Rad, Hercules, CA, USA) and the relative phosphorylation determined by densitometry (Quantity One, Bio-Rad).

Protein kinase $\mathrm{C}(\mathrm{PKC})$ activity was measured in confluent cultures of MSCs treated with vehicle $(0.01 \%$ acetic acid) or concentrations of protein/peptide (rAmel or NTAP) for 9 or $30 \mathrm{~min}$. After incubation, monolayers were washed twice with phosphate buffered saline (PBS) and lysed in radioimmunoprecipitation (RIPA) buffer. PKC activity was measured using a commercially available assay (GE Healthcare, Piscataway, NJ, USA) following the manufacturer's instructions. Phosphorylated ERK1/2 and ß-catenin were measured in confluent cultures of MSCs treated with vehicle $(0.01 \%$ acetic acid $)$ or concentrations of protein/peptide (rAmel or NTAP) for 30 or $90 \mathrm{~min}$ using commercially available ELISA kits (R\&D Systems). Biochemical assays were normalized to total protein in the cell lysate (Thermo Scientific Pierce BCA Protein Assay).

\section{Inhibitor study}

To determine the contribution of ERK1/2 signaling in NTAP-stimulated osteoblastic differentiation, cells were pre-treated for $30 \mathrm{~min}$ with 5 or $10 \mu \mathrm{M}$ U0126 (Cell Signaling Technology, Danvers, MA, USA) (Favata et al., 1998), which is a selective ERK1/2 inhibitor. Cells were then treated with $1 \mu \mathrm{g} / \mathrm{mL}$ rAmel or NTAP in the presence of the inhibitor for an additional $12 \mathrm{~h}$. RNA was harvested and real-time PCR performed to measure changes in $\mathrm{mRNA}$ levels as described above.

\section{Statistical analysis}

Data shown are from a single set of experiments and are presented as means \pm SEM of six independent cultures per variable. Power analysis using data sets generated in similar studies has shown that six cultures per variable tested under identical conditions are sufficient to demonstrate statistical significance if it exists. To ensure validity of the observations, the entire set of experiments was repeated a minimum of two times. If differences in the two data sets had been observed, the experiments would have been repeated an additional three times, so that data could be compared using treatment/control ratios and each separate set of experiments would be considered an $n$ of one. This did not prove to be necessary in the present study. Data were analyzed using analysis of variance (ANOVA) and significance between groups determined using Bonferroni's modification of Student's $t$-test. $p<0.05$ was considered significant.

\section{Results}

Neither rAmel nor NTAP affected the DNA content of the MSC cultures (Fig. 1a). rAmel and NTAP increased alkaline phosphatase specific activity, an early marker of osteoblast differentiation, at all concentrations tested; however, 1 or $10 \mu \mathrm{g} / \mathrm{mL}$ NTAP caused significantly higher alkaline phosphatase specific activity than the other treatments (Fig. 1b). Treatment with rAmel increased osteocalcin, a later marker of osteoblast differentiation, independent of dose (Fig. 1c). NTAP increased osteocalcin in a dose-dependent manner, with $10 \mu \mathrm{g} / \mathrm{mL}$ NTAP causing greater osteocalcin production than in all other groups.

rAmel caused higher secreted OPG at $1 \mu \mathrm{g} / \mathrm{mL}$, but cells treated with $10 \mu \mathrm{g} / \mathrm{mL}$ were not significantly different from control (Fig. 1d). However, cells treated with NTAP had $75 \%$ higher OPG than untreated cells, independent of concentration.

All treatments increased VEGF $50 \%$ over control cells, but there was no difference between treatments or concentrations (Fig. 1e). Cells treated with $10 \mu \mathrm{g} / \mathrm{mL}$ rAmel, but not $1 \mu \mathrm{g} / \mathrm{mL}$, significantly increased TGF- $\beta 1$ (Fig. 1f). NTAP increased TGF- $\beta 1$ at both 1 and $10 \mu \mathrm{g} /$ $\mathrm{mL}$, but the effect was lower at the higher concentration.

Both rAmel and NTAP increased RUNX2 mRNA expression over control (Fig. 2a) (NTAP $>$ rAmel). Cells treated with NTAP had the highest RUNX2 expression. Cells treated with NTAP had higher COL1 expression than 

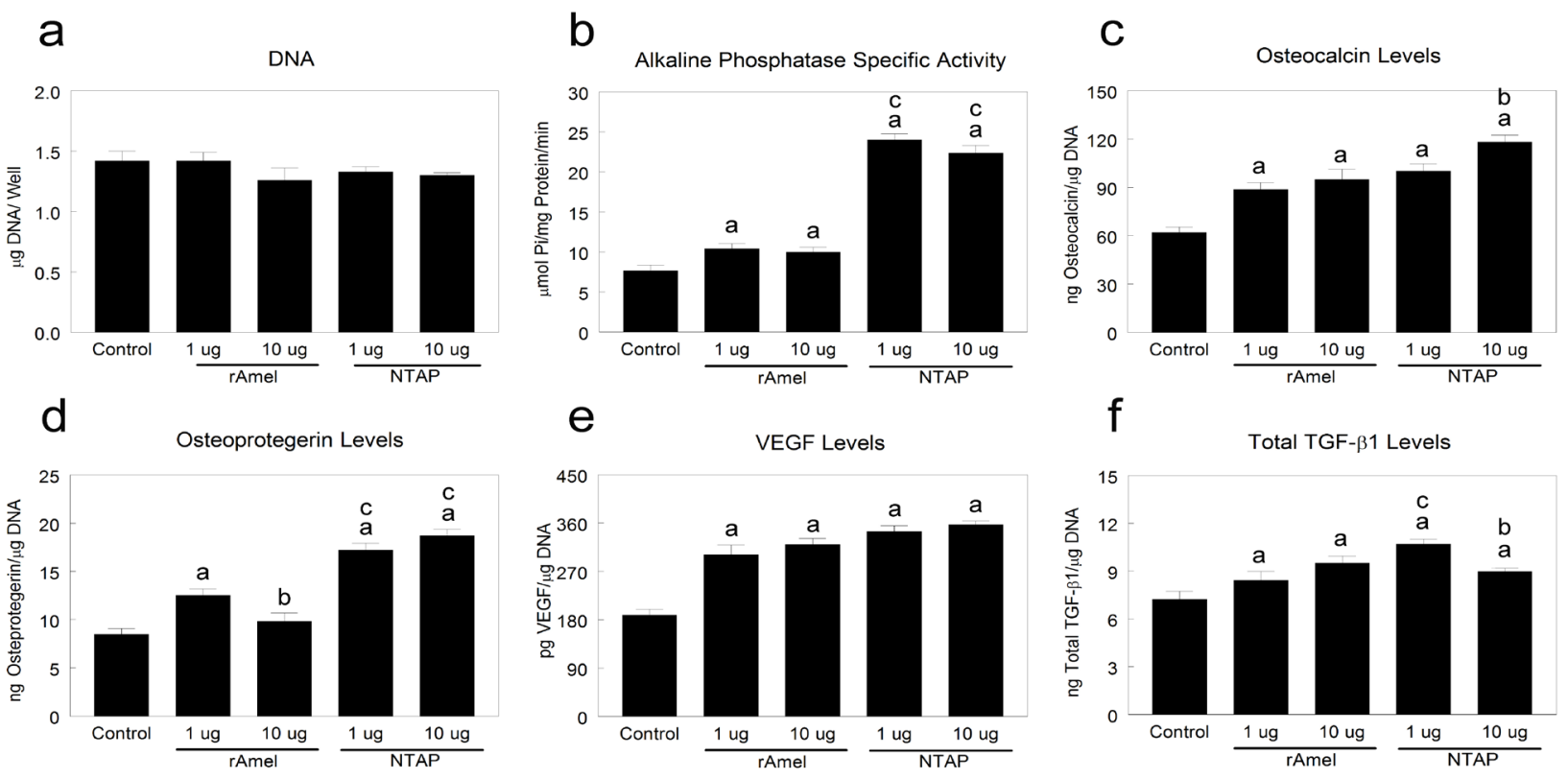

Fig. 1. Effect of recombinant human amelogenin and NTAP on DNA content, osteoblastic differentiation, and local factor production of MSCs. MSCs were grown to confluence and treated with $0.1 \%$ acetic acid (control) or $1 \mu \mathrm{g} / \mathrm{mL}$ or $10 \mu \mathrm{g} / \mathrm{mL}$ recombinant human amelogenin (rAmel) or NTAP for $24 \mathrm{~h}$. DNA content (a) and alkaline phosphatase specific activity (b) were measured in cell lysates and osteocalcin (c), osteoprotegerin (d), VEGF (e), and total TGF- $\beta 1$ (f) were measured in the conditioned media. a: $p<0.05, v s$. control; b: $p<0.05,10 \mu \mathrm{g} / \mathrm{mL} v s .1 \mu \mathrm{g} / \mathrm{mL}$ concentration; c: $p<0.05$, NTAP vs. rAmel.

Fig. 2. Effect of recombinant human amelogenin and NTAP on osteogenic gene expression in MSCs. MSCs were grown to confluence and treated with $0.1 \%$ acetic acid (control) or $1 \mu \mathrm{g} / \mathrm{mL}$ or $10 \mu \mathrm{g} / \mathrm{mL}$ recombinant human amelogenin (rAmel) or NTAP for 12 h. Expression of RUNX2 (a), COL1 (b), OCN (c), and OPG (d) were measured by quantitative real-time PCR. a: $p<0.05$, vs. control; b: $p<0.05,10 \mu \mathrm{g} / \mathrm{mL}$ vs. $1 \mu \mathrm{g} / \mathrm{mL}$ concentration; c: $p<0.05$, NTAP vs. rAmel.
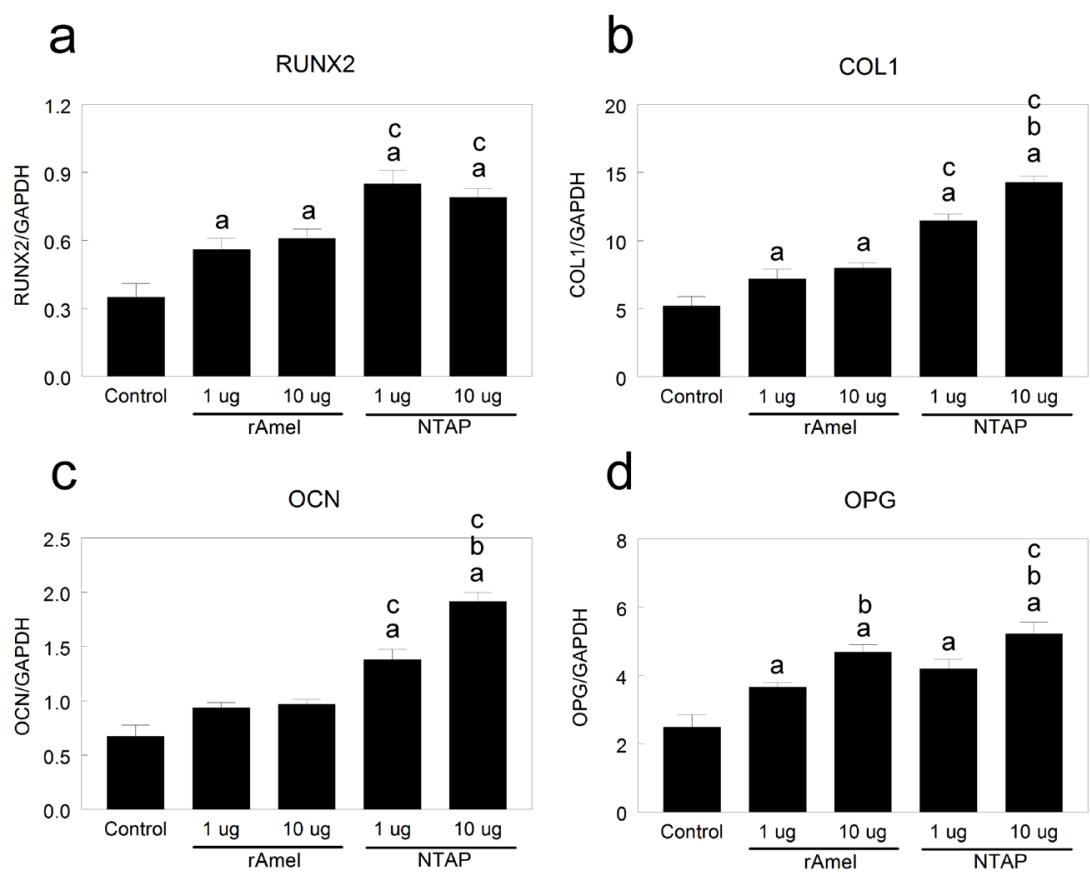

cells treated with rAmel, with the greatest effect at $10 \mu \mathrm{g} /$ $\mathrm{mL}$ dose (Fig. 2b). NTAP increased OCN expression in a dose-dependent manner over untreated cells, while rAmel produced no effect (Fig. 2c). At $1 \mu \mathrm{g} / \mathrm{mL}$, both rAmel and NTAP produced similar increases in OPG mRNA levels as compared to untreated cells (Fig. 2d). Cells treated with $10 \mu \mathrm{g} / \mathrm{mL}$ rAmel had a $100 \%$ higher OPG in comparison to control cells, but $10 \mu \mathrm{g} / \mathrm{mL}$ NTAP produced the greatest effect.
Treatment with NTAP caused a 2-fold or greater phosphorylation in eight of the 46 proteins examined in the array (Fig. 3). PKC activity was significantly increased after $9 \mathrm{~min}$ of treatment with $10 \mu \mathrm{g} / \mathrm{mL}$ rAmel (Fig. 4a). NTAP increased PKC at both concentrations to a similar extent. After 30 min of treatment, all treatments yielded similar PKC levels to control (Fig. 4b). Levels of phosphorylated ERK1/2 were significantly higher in cells treated with rAmel and NTAP in comparison to control 


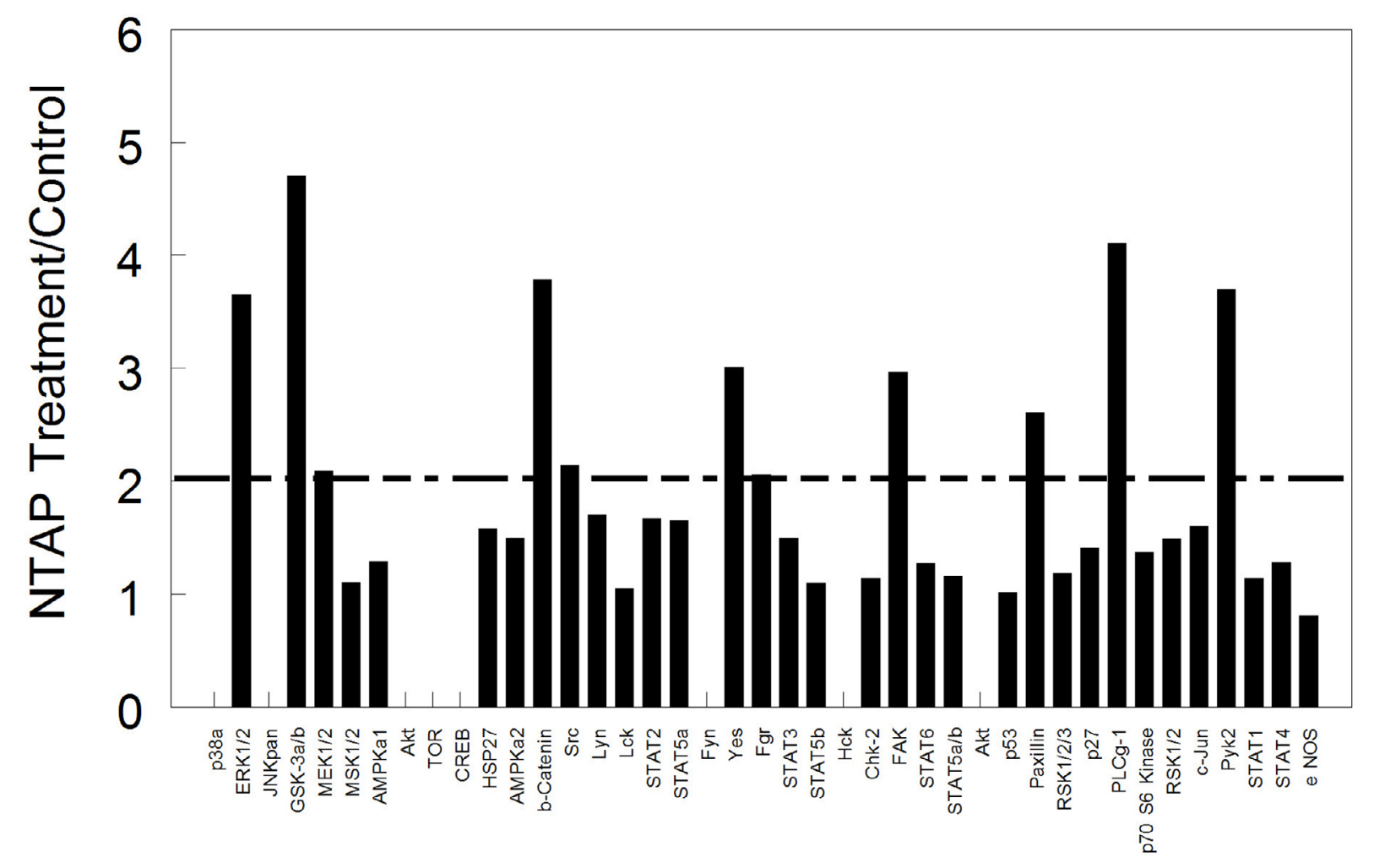

Fig. 3. Effect of recombinant human amelogenin and NTAP on kinase activity in MSCs. Confluent cultures of MSCs were treated with $0.1 \%$ acetic acid (control) or $1 \mu \mathrm{g} / \mathrm{mL}$ recombinant human amelogenin (rAmel) or NTAP for $30 \mathrm{~min}$. Cell lysates were analyzed by modified Western blot for levels of 46 proteins and densitometry analysis performed.
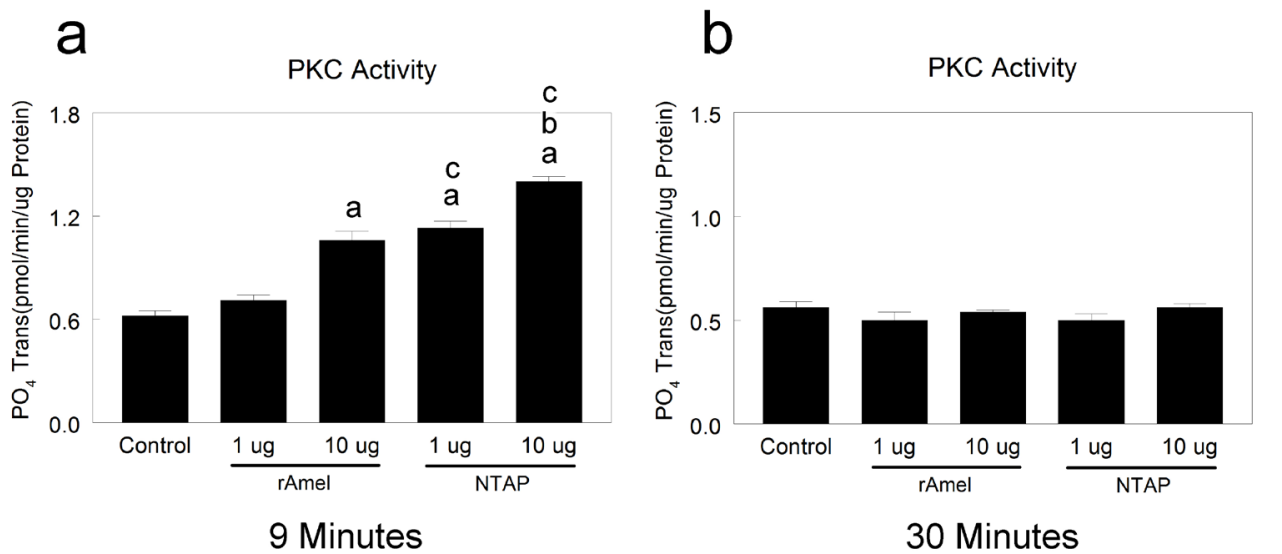

Fig. 4. Effect of recombinant human amelogenin and NTAP on protein kinase C activity in MSCs. MSCs were grown to confluence and treated with $0.1 \%$ acetic acid (control) or $1 \mu \mathrm{g} / \mathrm{mL}$ or $10 \mu \mathrm{g} / \mathrm{mL}$ recombinant human amelogenin (rAmel) or NTAP. Protein kinase C (PKC) activity was measured after $9 \min (\mathbf{a})$ or $30 \mathrm{~min}(\mathbf{b})$ of treatment. a: $p<0.05$, vs. control; b: $p<0.05,10 \mu \mathrm{g} / \mathrm{mL} v s .1 \mu \mathrm{g} / \mathrm{mL}$ concentration; c: $p<0.05$, NTAP $v s$. rAmel.

at $30 \mathrm{~min}$, but the effect was not dependent on dose (Fig. $5 \mathrm{~A})$. After $90 \mathrm{~min}$ treatment, cells treated with $10 \mu \mathrm{g} / \mathrm{mL}$ rAmel or either concentration of NTAP had significantly higher phosphorylated ERK1/2 levels in comparison to untreated cells (Fig. 5B). Phosphorylated $\beta$-catenin was increased in MSCs treated with rAmel for $30 \mathrm{~min}$, but the effect was not dependent on dose (Fig. 6A). Treatment with $1 \mu \mathrm{g} / \mathrm{mL}$ NTAP yielded similar levels of phosphorylated $\beta$-catenin, but the greatest effect was seen in cells treated with $10 \mu \mathrm{g} / \mathrm{mL}$ NTAP. rAmel produced a similar effect at $90 \mathrm{~min}$, but cells treated with NTAP had the greatest effect at $1 \mu \mathrm{g} / \mathrm{mL}$ dose (Fig. 6B).
Increases in mRNA levels for RUNX2 (Fig. 7A) and ALP (Fig. 7B) that were stimulated by rAmel and NTAP, were blocked by the ERK1/2 inhibitor U0126. The presence of $5 \mu \mathrm{M}$ U0126 partially inhibited the increase in OCN (Fig. 7C) and COL1 (Fig. 7D) stimulated by rAmel and NTAP. These increases were abolished by the high dose of inhibitor. ERK1/2 inhibition had no effect on rAmel- and NTAP-stimulated OPG increases (Fig. 7E). ERK1/2 inhibition blocked increased BMP2 mRNA levels stimulated by rAmel and NTAP (Fig. 7F). 
A

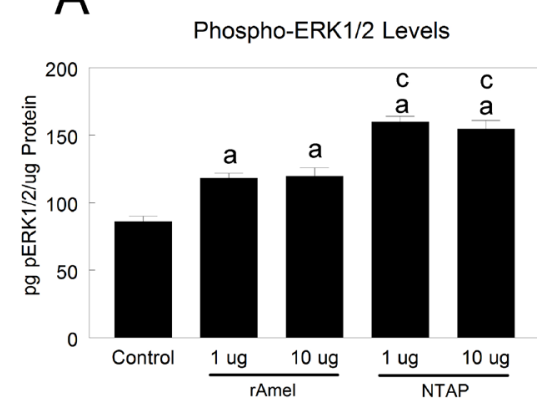

30 Minutes

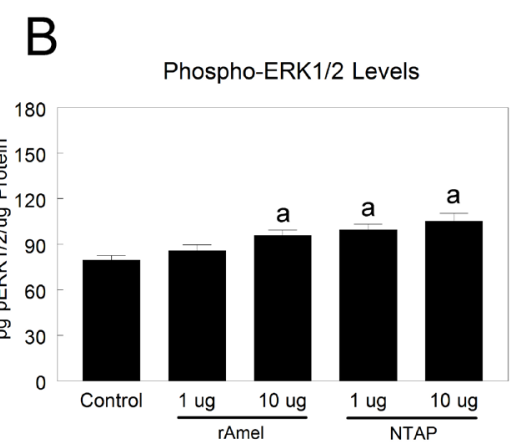

90 Minutes

Fig. 5. Effect of recombinant human amelogenin and NTAP on levels of phosphorylated ERK1/2 in MSCs. MSCs were grown to confluence and treated with $0.1 \%$ acetic acid (control) or $1 \mu \mathrm{g} / \mathrm{mL}$ or $10 \mu \mathrm{g} / \mathrm{mL}$ recombinant human amelogenin (rAmel) or NTAP. Levels of phosphorylated ERK1/2 were measured after $30 \mathrm{~min}(\mathbf{A})$ or $90 \mathrm{~min}(\mathbf{B})$ of treatment. a: $p<0.05, v s$. control; b: $p<0.05,10 \mu \mathrm{g} / \mathrm{mL} v s .1 \mu \mathrm{g} / \mathrm{mL}$ concentration; c: $p<0.05$, NTAP $v s$. rAmel.

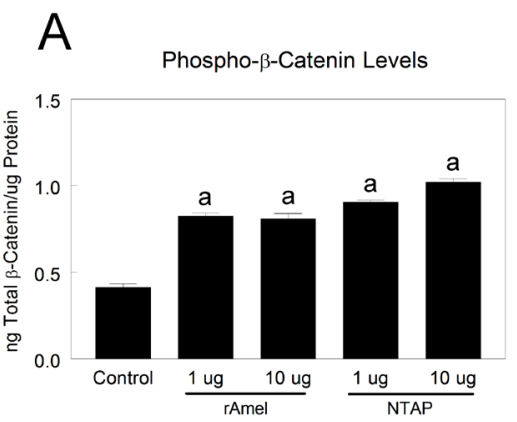

30 Minutes

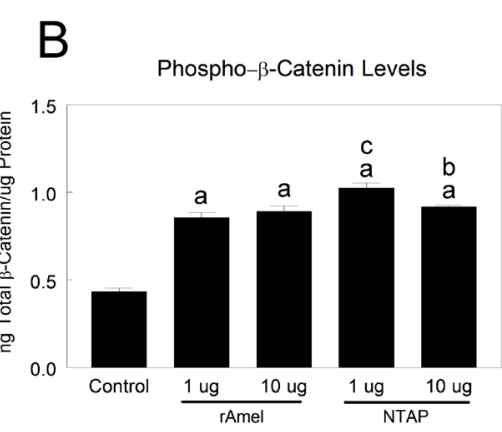

90 Minutes

Fig. 6. Effect of recombinant human amelogenin and NTAP on levels of phosphorylated ß-catenin in MSCs. MSCs were grown to confluence and treated with $0.1 \%$ acetic acid (control) or $1 \mu \mathrm{g} / \mathrm{mL}$ or $10 \mu \mathrm{g} / \mathrm{mL}$ recombinant human amelogenin (rAmel) or NTAP. Levels of phosphorylated $\beta$-catenin were measured after $30 \mathrm{~min}$ (A) or $90 \mathrm{~min}(\mathbf{B})$ of treatment. a: $p<0.05$, vs. control; b: $p<0.05,10 \mu \mathrm{g} / \mathrm{mL} v s .1 \mu \mathrm{g} / \mathrm{mL}$ concentration; c: $p<0.05$, NTAP vs. rAmel.
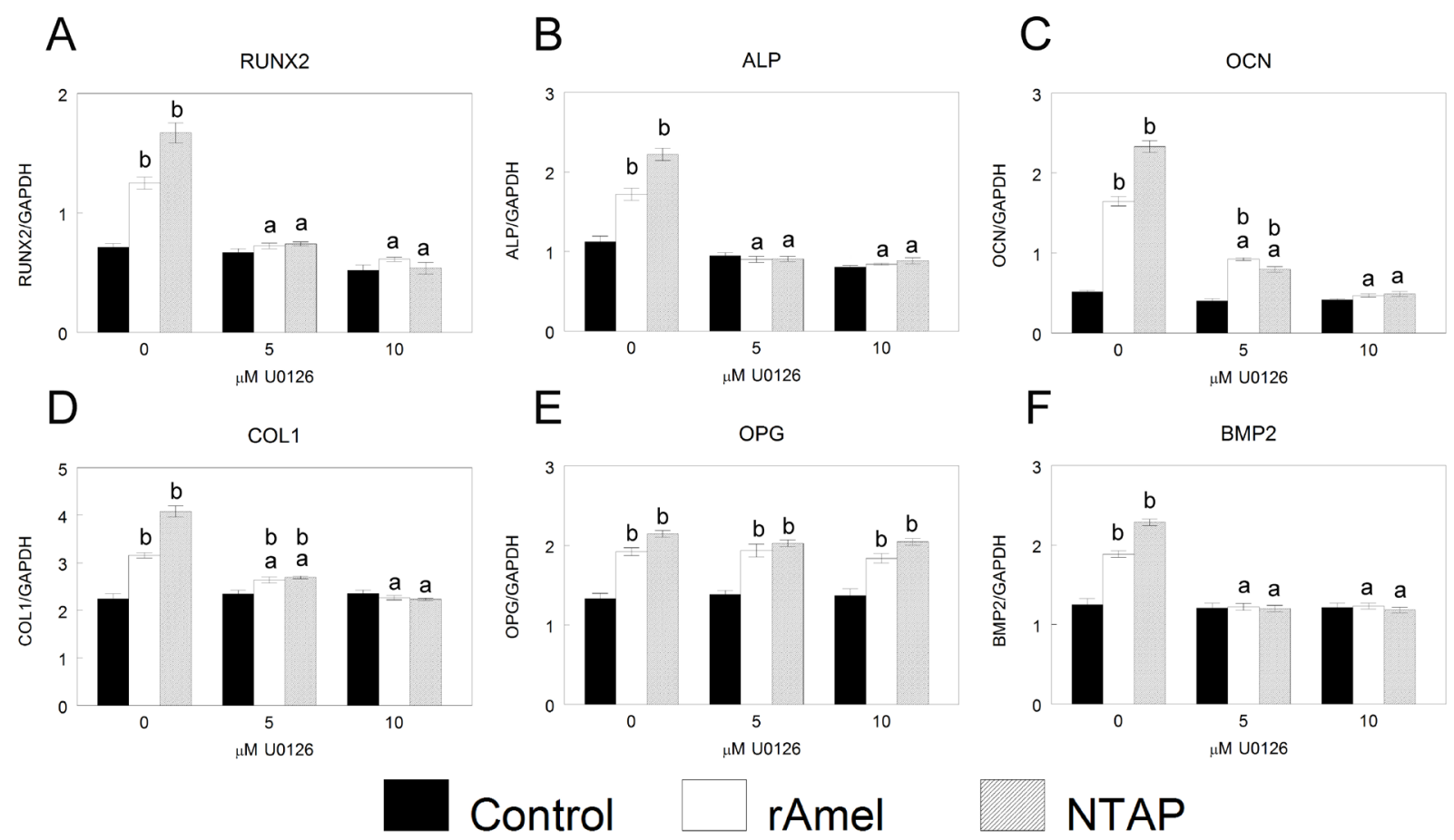

rAmel

\section{NTAP}

Fig. 7. Effect of ERK1/2 inhibition on osteogenic effects of recombinant human amelogenin and NTAP in MSCs. Confluent cultures of MSCs were incubated with ERK1/2 inhibitor U0126 for $30 \mathrm{~min}$. After $30 \mathrm{~min}, 0.1 \%$ acetic acid (control) or $1 \mu \mathrm{g} / \mathrm{mL}$ recombinant human amelogenin (rAmel) or NTAP were added to inhibitors. mRNA levels of RUNX2 (A), ALP (B), OCN (C), COL1 (D), OPG (E), and BMP2 (F) were measured by real-time PCR. a: $p<0.05$, vs. $0 \mu \mathrm{M}$ inhibitor; b: $p<0.05$, vs. control. 


\section{Discussion}

Amelogenin, the major component of enamel matrix derivatives from a number of species, has been suggested as the active factor responsible for pEMD's therapeutic effect. Amelogenin can be found as full-length protein, alternative splicing isoforms, or as proteolytically formed peptides (Veis, 2003). However, it is not completely understood if all of these molecules have biological activity or affect progenitor cells. Amelogenin usually is divided into 3 domains: an N-terminal tyrosine-rich domain (TRAP), a central hydrophobic domain, and a hydrophilic C-terminal domain (Bartlett and Simmer, 1999). It has been shown that the $\mathrm{C}$-terminal domain, which contains the charged residues of amelogenin, plays a critical role in the interaction of amelogenin with hydroxyapatite (HA) surfaces and in crystal growth inhibition. This has been further demonstrated when the C-terminal domain was removed enzymatically, decreasing amelogenin's affinity for HA. Additionally, the C-terminal domain is essential for amelogenin self-assembly and contributes to formation of amelogenin nanospheres (Paine et al., 2003). While most studies focus on the effect of amelogenin and the C-terminal domain, the goal of our study was to examine the signaling induced by a $5 \mathrm{kDa}$ peptide corresponding to the N-terminal portion of amelogenin.

Our results showed that amelogenin induced osteoblastic differentiation of MSCs, resulting in an increase in alkaline phosphatase activity and osteocalcin levels, in basal mesenchymal stem cell media without addition of exogenous factors such as dexamethasone or $\beta$-glycerophosphate. In addition, exposure of MSCs to NTAP showed a strong increase in RUNX2 mRNA in comparison to amelogenin and control treatments, suggesting that the $\mathrm{N}$-terminal portion of amelogenin may be responsible for RUNX2 gene expression. Taken together, the results demonstrate that NTAP induces a more robust osteoblastic effect in MSCs than amelogenin.

It is likely that other constituents in pEMD also contribute to osteoblast differentiation of MSCs in vivo. Previous studies have shown that a low molecular weight (LMW) peptide containing the tyrosine-rich amelogenin peptide (TRAP) has an osteoblastic effect on periodontal ligament fibroblasts (PDL) (Amin et al., 2013), demonstrated by increased RUNX2, osteopontin (OPN), OCN, and bone sialoprotein (BSP) mRNA levels, and alkaline phosphatase specific activity. However, that study used a higher dose of LMW amelogenin $(100 \mu \mathrm{g} /$ $\mathrm{mL}$ ) and osteogenic induction media, making it difficult to decouple the direct effects of enamel matrix derivative or its constituents from the effects of the culture media. Our results confirm previous studies in which cells increased secretion of TGF- $\beta 1$ after stimulation by $\mathrm{pEMD}$ (Gestrelius et al., 1997; Warotayanont et al., 2009). MSCs treated with amelogenin or NTAP increased TGF- $\beta 1$ in our study, suggesting that this effect of pEMD is due to these components.

Cells participating in bone formation not only mineralize their extracellular matrix but also create a microenvironment that modulates angiogenesis. VEGF-A, important for endothelial cell recruitment and blood vessel sprouting, was stimulated by both amelogenin and NTAP in our study. Previous studies support these results, indicating that human microvascular endothelial cells and human dermal fibroblasts increased production of VEGF after enamel matrix derivative application (Kauvar et al., 2010; Thoma et al., 2011).

Bone regeneration also depends on net new bone formation, which can be achieved by controlling osteoclastic activity. OPG functions as a decoy receptor for receptor activator of nuclear factor kappa $\mathrm{B}$ ligand (RANKL), binding RANKL and inhibiting osteoclast maturation and activation. Our results showed that NTAP increased mRNA and protein levels of OPG in a more robust manner than amelogenin treatment. These results support previous studies where enamel matrix derivative increased OPG mRNA in MC3T3-E1 cells (He et al., 2004), and increased OPG protein levels and decreased RANKL levels in human mandibular osteoblasts (Galli et al., 2006). It is important to note that NTAP increased protein levels of both OPG and TGF- $\beta 1$ in this study. TGF- $\beta 1$ also modulates osteoclast activity (Bonewald and Mundy, 1990). Moreover, previous studies have shown that TGF- $\beta 1$ increases production of OPG and antibody blocking or soluble TGF- $\beta$ receptor type 2 inhibits OPG production (Schwartz et al., 2009). Taken together, these results suggest that amelogenin, and specifically the $\mathrm{N}$-terminal portion, tightly modulates OPG production by two mechanisms, directly through increasing mRNA levels and indirectly through increasing TGF- $\beta 1$ levels. Interestingly, purified fractions of enamel matrix derivative enhance the formation and activation of osteoclasts in mouse monocytic RAW 264.7 cells (Itoh et al., 2006). It is possible that the specific fraction used to induce osteoclast activation is different from the $\mathrm{N}$-terminal portion, or that amelogenin and NTAP have different roles in osteoprogenitor/osteoblast cells and monocytes/immune cells.

The amelogenin knockout mouse has a hypomineralization phenotype, supporting the hypothesis that amelogenin, its splice variants, and proteolytic peptides differentially contribute to mineral homeostasis (Gibson et al., 2001). Both amelogenin and NTAP increased levels of important local factors involved in the production of an osteogenic environment. These results suggest that fulllength amelogenin or the N-terminal portion of amelogenin not only induce osteoblastic differentiation of MSCs, but also induce MSCs to produce a local environment that can support angiogenesis and modulate osteoclast activity.

Numerous studies have shown the in vitro, in vivo, and clinical importance of enamel matrix derivative in periodontal regeneration (Esposito et al., 2009; Gestrelius et al., 2000; Grandin et al., 2012; Kalpidis and Ruben, 2002; Venezia et al., 2004). However, the molecular signaling mechanisms of amelogenin or the different fractions in pEMD are not clear. Several amelogenin receptors have been proposed (Shapiro et al., 2007), however less is known about the signaling events that amelogenin or amelogenin peptides induce in cells. Here we showed that NTAP induces phosphorylation of kinases involved in $\mathrm{Ca}^{2+}$ signaling and cytoskeleton signaling, such as GS3K, ERK1/2, Yes, FAK, PLC, Paxillin, and Pyk2. 
Our results suggest that NTAP is not just a peptide or a structural protein but also is capable of inducing signaling pathways that can involve $\mathrm{Ca}^{2+}$ influx and cytoskeleton rearrangement.

In this study, amelogenin and NTAP increased PKC activity, ERK1/2 phosphorylation, and $\beta$-catenin phosphorylation. PKC plays an important role in several signal transduction cascades that affect cell growth, differentiation, cytoskeleton rearrangement, transcriptional control, and apoptosis (Zeng et al., 2012). Other studies using signal pathway inhibitors showed that LRAP increased OCN mRNA levels via PKC and ERK1/2 (Boabaid et al., 2004). However, it is unlikely that LRAP directly activated PKC or ERK1/2 in that study since the length of treatment was $72 \mathrm{~h}$, enough time for the cells to produce and release secreted factors to affect the cells in an autocrine and paracrine fashion, activating these signaling pathways. In contrast, our study showed direct activation of PKC 9 min after treatment with amelogenin or NTAP.

MAP kinases mediate several intracellular signaling cascades that result in cell proliferation, differentiation, survival, and apoptosis (Boabaid et al., 2004). ERK was the only MAP kinase responsive to $\mathrm{pEMD}$ in periodontal ligament cells (Matsuda et al., 2002). Amelogenin induced ERK phosphorylation in cementoblasts (Kunimatsu et al., 2011), MSCs, and gingival fibroblasts (Li et al., 2010). Our study showed that NTAP increased phosphorylation of ERK1/2 at $15 \mathrm{~min}$ and this phosphorylation modulated MSC osteogenic differentiation. In addition, inhibition of ERK1/2 phosphorylation by U0126 abolished NTAPdependent increases in RUNX2, ALP, OCN, COL1, OPG, and BMP2 mRNA levels, suggesting that the N-terminal portion of amelogenin is responsible for ERK $1 / 2$ activation and the subsequent signaling cascade.

Previous studies have suggested that amelogenin induced osteogenesis by activation of the Wnt/ $\beta$ catenin pathway (Warotayanont et al., 2009), which is characterized by accumulation of $\beta$-catenin in the cytoplasm and its further translocation to the nucleus. Without stimulation of the canonical pathway, $\beta$-catenin is targeted for ubiquitination. Several studies have shown that LRAP elevated activated $\mathrm{Wnt} / \beta$-catenin signaling in mouse embryoid bodies, MC3T3-E1 cells, osteoblasts, and PDL cells (Warotayanont et al., 2008; Warotayanont et al., 2009). However, recent reports have demonstrated that the Wnt/ $\beta$-catenin pathway suppresses osteogenic differentiation in MSCs and instead supports self-renewal and maintenance of the less differentiated phenotype (Baksh and Tuan, 2007). Additionally, PKC activation induces reduction in $\beta$-catenin (Lovatt and Bijlmakers, 2010). Our study showed an increase in PKC activity and $\beta$-catenin phosphorylation after treatment with amelogenin or NTAP, suggesting that $\mathrm{Wnt} / \beta$-catenin signaling is not active in our model.

Despite the demonstrated benefits in vivo and clinically, it remains unknown how pEMD is involved in cell adhesion, proliferation, and differentiation due to the diverse cell populations of the periodontium. In vitro studies have used a wide variety of cells to examine the effect of enamel matrix derivative and amelogenin on cellmatrix interactions. Studies have examined the response of a variety of epithelial and mesenchymal cell types to enamel matrix proteins (Boabaid et al., 2004; Nagano et al., 2004; Song et al., 2010; van den Dolder et al., 2006; Zeldich et al., 2007), but only a portion of the complete mechanism of pEMD is known (Bosshardt et al., 2005). Previous studies from our lab have demonstrated that NTAP induces osteoblast maturation and yields a protective effect against osteoblast apoptosis (Olivares-Navarrete et al., 2013). Increased alkaline phosphatase activity and production of osteocalcin, osteopontin, and bone sialoprotein are commonly reported after treatment with enamel matrix derivative in mineralizing cell types (Grandin et al., 2012). Clinical case reports have demonstrated that the application of pEMD leads to regeneration of the surrounding tissue and formation of a functional attachment (Esposito et al., 2009).

Extracellular matrix mineralization in vitro (OlivaresNavarrete et al., 2013) and bone regeneration in vivo (Esposito et al., 2009) have been reported after enamel matrix derivative application. Here we detail the osteogenic induction capacity of full-length amelogenin in MSCs, the first cells to colonize the site of repair and initiate regeneration, an effect more robust in cells treated with the peptide corresponding to the $\mathrm{N}$-terminal portion of amelogenin. The results demonstrate that both amelogenin and NTAP induce osteoblastic differentiation of MSCs and stimulate production of osteogenic factors, and that the effects of the extracellular matrix protein NTAP are mediated through activation of PKC and ERK1/2 and degradation of $\beta$-catenin.

\section{Acknowledgements}

Institut Straumann provided NTAP and recombinant amelogenin as a gift. The authors would like to thank Dr. Corina Mauth for her assistance with manuscript preparation. We wish to confirm that there are no known conflicts of interest associated with this publication and there has been no significant financial support for this work that could have influenced its outcome.

\section{References}

Amin HD, Olsen I, Knowles JC, Dard M, Donos N (2013) Effects of enamel matrix proteins on multi-lineage differentiation of periodontal ligament cells in vitro. Acta Biomater 9: 4796-4805.

Baksh D, Tuan RS (2007) Canonical and non-canonical Wnts differentially affect the development potential of primary isolate of human bone marrow mesenchymal stem cells. J Cell Physiol 212: 817-826.

Bartlett JD, Simmer JP (1999) Proteinases in developing dental enamel. Crit Rev Oral Biol Med 10: 425-441.

Boabaid F, Gibson CW, Kuehl MA, Berry JE, Snead ML, H. NF,Jr, Katchburian E, Somerman MJ (2004) Leucine-rich amelogenin peptide: a candidate signaling molecule during cementogenesis. J Periodontol 75: 11261136. 
Bonewald LF, Mundy GR (1990) Role of transforming growth factor-beta in bone remodeling. Clin Orthop Relat Res 250: 261-276.

Bosshardt DD, Sculean A, Windisch P, Pjetursson BE, Lang NP (2005) Effects of enamel matrix proteins on tissue formation along the roots of human teeth. J Periodontal Res 40: 158-167.

Brookes SJ, Robinson C, Kirkham J, Bonass WA (1995) Biochemistry and molecular biology of amelogenin proteins of developing dental enamel. Arch Oral Biol 40: $1-14$.

Esposito M, Grusovin MG, Papanikolaou N, Coulthard P, Worthington HV (2009) Enamel matrix derivative $($ Emdogain $(\mathrm{R}))$ for periodontal tissue regeneration in intrabony defects. Cochrane Database Syst Rev CD003875.

Favata MF, Horiuchi KY, Manos EJ, Daulerio AJ, Stradley DA, Feeser WS, Van Dyk DE, Pitts WJ, Earl RA, Hobbs F, Copeland RA, Magolda RL, Scherle PA, Trzaskos JM (1998) Identification of a novel inhibitor of mitogen-activated protein kinase kinase. J Biol Chem 273: 18623-18632.

Fincham AG, Moradian-Oldak J (1993) Amelogenin post-translational modifications: carboxy-terminal processing and the phosphorylation of bovine and porcine "TRAP" and "LRAP" amelogenins. Biochem Biophys Res Commun 197: 248-255.

Galli C, Macaluso GM, Guizzardi S, Vescovini R, Passeri M, Passeri G (2006) Osteoprotegerin and receptor activator of nuclear factor-kappa B ligand modulation by enamel matrix derivative in human alveolar osteoblasts. J Periodontol 77: 1223-1228.

Gestrelius S, Andersson C, Lidstrom D, Hammarstrom L, Somerman M (1997) In vitro studies on periodontal ligament cells and enamel matrix derivative. J Clin Periodontol 24: 685-692.

Gestrelius S, Lyngstadaas SP, Hammarstrom L (2000) Emdogain--periodontal regeneration based on biomimicry. Clin Oral Invest 4: 120-125.

Gibson CW, Yuan ZA, Hall B, Longenecker G, Chen E, Thyagarajan T, Sreenath T, Wright JT, Decker S, Piddington R, Harrison G, Kulkarni AB (2001) Amelogenin-deficient mice display an amelogenesis imperfecta phenotype. J Biol Chem 276: 31871-31875.

Grandin HM, Gemperli AC, Dard M (2012) Enamel matrix derivative: A review of cellular effects and a model of molecular arrangement and functioning. Tissue Eng Part B Rev 18: 181-202.

He J, Jiang J, Safavi K, Spangberg L, Zhu Q (2004) Emdogain promotes osteoblast proliferation and differentiation and stimulates osteoprotegerin expression1. Oral Surg Oral Med Oral Pathol Oral Radiol Endod 97: 239-245.

Itoh N, Kasai H, Ariyoshi W, Harada E, Yokota M, Nishihara T (2006) Mechanisms involved in the enhancement of osteoclast formation by enamel matrix derivative. J Periodontal Res 41: 273-279.

Kalpidis CD, Ruben MP (2002) Treatment of intrabony periodontal defects with enamel matrix derivative: a literature review. J Periodontol 73: 1360-1376.
Kauvar AS, Thoma DS, Carnes DL, Cochran DL (2010) In vivo angiogenic activity of enamel matrix derivative. $\mathrm{J}$ Periodontol 81: 1196-1201.

Kawana F, Sawae Y, Sahara T, Tanaka S, Debari K, Shimizu M, Sasaki T (2001) Porcine enamel matrix derivative enhances trabecular bone regeneration during wound healing of injured rat femur. Anat Rec 264: 438-446.

Komori T (2010) Regulation of osteoblast differentiation by Runx2. Adv Exp Med Biol 658: 43-49.

Kunimatsu R, Tanimoto K, Tanne Y, Kamiya T, Ohkuma S, Huang YC, Yoshimi Y, Miyauchi M, Takata T, Tanne K (2011) Amelogenin enhances the proliferation of cementoblast lineage cells. J Periodontol 82: 1632-1638.

Le Norcy E, Kwak SY, Wiedemann-Bidlack FB, Beniash E, Yamakoshi Y, Simmer JP, Margolis HC (2011) Leucine-rich amelogenin peptides regulate mineralization in vitro. J Dent Res 90: 1091-1097.

Li X, Shu R, Liu D, Jiang S (2010) Different effects of $25-\mathrm{kDa}$ amelogenin on the proliferation, attachment and migration of various periodontal cells. Biochem Biophys Res Commun 394: 581-586.

Lovatt M, Bijlmakers MJ (2010) Stabilisation of betacatenin downstream of $\mathrm{T}$ cell receptor signalling. PLoS One 5: e12794.

Lyngstadaas SP, Lundberg E, Ekdahl H, Andersson C, Gestrelius S (2001) Autocrine growth factors in human periodontal ligament cells cultured on enamel matrix derivative. J Clin Periodontol 28: 181-188.

Matsuda N, Horikawa M, Watanabe M, Kitagawa S, Kudo Y, Takata T (2002) Possible involvement of extracellular signal-regulated kinases $1 / 2$ in mitogenic response of periodontal ligament cells to enamel matrix derivative. Eur J Oral Sci 110: 439-444.

Mirastschijski U, Konrad D, Lundberg E, Lyngstadaas SP, Jorgensen LN, Agren MS (2004) Effects of a topical enamel matrix derivative on skin wound healing. Wound Repair Regen 12: 100-108.

Mumulidu A, Hildebrand B, Fabi B, Hammarström L, Cochran DL, Dard M, Lemoult S (2007) Purification and analysis of a $5 \mathrm{kDa}$ component of enamel matrix derivative. J Chromatogr B 857: 210-218.

Mundy GR (1991) The effects of TGF-beta on bone. Ciba Found Symp 157: 137-43.

Nagano T, Iwata T, Ogata Y, Tanabe T, Gomi K, Fukae M, Arai T, Oida S (2004) Effect of heat treatment on bioactivities of enamel matrix derivatives in human periodontal ligament (HPDL) cells. J Periodontal Res 39: 249-256.

Nagano T, Kakegawa A, Yamakoshi Y, Tsuchiya S, Hu JC, Gomi K, Arai T, Bartlett JD, Simmer JP (2009) Mmp20 and Klk4 cleavage site preferences for amelogenin sequences. J Dent Res 88: 823-828.

Olivares-Navarrete R, Hyzy SL, Almaguer-Flores A, Mauth C., Gemperli AC, Boyan BD, Schwartz Z (2013) Amelogenin peptide extract increases differentiation, angiogenic and local factor production, and inhibits apoptosis in human osteoblasts. ISRN Biomater 2013: 347318.

Paine ML, Wang HJ, Snead ML (2003) Amelogenin self-assembly and the role of the proline located within 
the carboxyl-teleopeptide. Connect Tissue Res 44 Suppl 1: 52-57.

Raines AL, Olivares-Navarrete R, Wieland M, Cochran DL, Schwartz Z, Boyan BD (2010) Regulation of angiogenesis during osseointegration by titanium surface microstructure and energy. Biomaterials 31: 4909-4917.

Schwartz Z, Olivares-Navarrete R, Wieland M, Cochran DL, Boyan BD (2009) Mechanisms regulating increased production of osteoprotegerin by osteoblasts cultured on microstructured titanium surfaces. Biomaterials 30: 3390-3396.

Shapiro JL, Wen X, Okamoto CT, Wang HJ, Lyngstadaas SP, Goldberg M, Snead ML, Paine ML (2007) Cellular uptake of amelogenin, and its localization to CD63, and Lamp1-positive vesicles. Cell Mol Life Sci 64: 244-256.

Song ZC, Shu R, Zhang XL (2010) Cellular responses and expression profiling of human bone marrow stromal cells stimulated with enamel matrix proteins in vitro. Cell Prolif 43: 84-94.

Thoma DS, Villar CC, Carnes DL, Dard M, Chun YH, Cochran DL (2011) Angiogenic activity of an enamel matrix derivative (EMD) and EMD-derived proteins: an experimental study in mice. J Clin Periodontol 38: 253-260.

van den Dolder J, Vloon AP, Jansen JA (2006) The effect of Emdogain on the growth and differentiation of rat bone marrow cells. J Periodontal Res 41: 471-476.

Veis A (2003) Amelogenin gene splice products: potential signaling molecules. Cell Mol Life Sci 60: 38-55.

Venezia E, Goldstein M, Boyan BD, Schwartz Z (2004) The use of enamel matrix derivative in the treatment of periodontal defects: a literature review and meta-analysis. Crit Rev Oral Biol Med 15: 382-402.

Warotayanont R, Zhu D, Snead ML, Zhou Y (2008) Leucine-rich amelogenin peptide induces osteogenesis in mouse embryonic stem cells. Biochem Biophys Res Commun 367: 1-6.

Warotayanont R, Frenkel B, Snead ML, Zhou Y (2009) Leucine-rich amelogenin peptide induces osteogenesis by activation of the Wnt pathway. Biochem Biophys Res Commun 387: 558-563.

Yao N, Li S, Jiang Y, Qiu S, Tan Y (2011) Amelogenin promotes odontoblast-like MDPC-23 cell differentiation via activation of ERK1/2 and p38 MAPK. Mol Cell Biochem 355: 91-97.

Zeldich E, Koren R, Dard M, Nemcovsky C, Weinreb M (2007) Enamel matrix derivative protects human gingival fibroblasts from TNF-induced apoptosis by inhibiting caspase activation. J Cell Physiol 213: 750-758.

Zeng L, Webster SV, Newton PM (2012) The biology of protein kinase C. Adv Exp Med Biol 740: 639-661.

\section{Discussion with Reviewers}

Reviewer I: I could not avoid wondering if the authors have done or have plans of doing similar experiments with an amelogenin peptide with the NTAP deleted. I would think this will show unequivocally the importance of this small peptide in the osteogenic differentiation.

Authors: We envision this experiment in our future research program with amelogenin. While we have explored several small peptides and their effects on mesenchymal stem cells, osteoblasts, and other mineralizing cell types, the suggested study would contribute to our understanding of the functions of the different portions of amelogenin on mineral tissue formation.

Reviewer II: There is often a confusion between scientific papers dedicated to cell biology and enamel peptides and translation towards the usefulness of commercial mixture of peptides. There should exist a clearer scission between basic sciences and applications.

Authors: We appreciate the reviewer's concern that scientific inquiry not be confused with commercial applications. However, it would be a shame to divorce the two completely for a number of reasons. The commercial product at issue here is a complex protein mixture formulated with a carrier, which may or may not have a biological consequence. The scientific literature is problematic to the extent that authors have used the terms EMD, enamel matrix derivative, and the product name interchangeably, making it difficult to know exactly what was used in a particular study. Porcine EMD that is generated by the company is consistent in composition, whereas laboratory-generated EMD or partially purified enamel matrix proteins may vary in composition depending on the methods used and the source of the tissue. Even when the commercial version without the carrier is used experimentally in a university laboratory, there is relatively little known about the function of many of the constituents. Similarly, the identity of each component is not known. The dominant protein, amelogenin, is certainly studied in purified form, but not every protein in EMD is amelogenin and to make matters more difficult, amelogenin-derived peptides are also present in the extract. Thus, clinicians, who also read scientific journals, have little concrete information about what is in porcine EMD and just like any scientist, have a right to this information. We recognize that this is a long answer to a simple question, but the reviewer has correctly hit on an important topic that is at the forefront of issues related to conflict of interest, the role of industry sponsorship of research, and the pervasive demand of the public to see basic science translated into clinical practice. 